\title{
PELATIHAN PENYUSUNAN PERATURAN DESA DI DESA PEMOGAN KECAMATAN DENPASAR SELATAN
}

\author{
Astariyani.NLG ${ }^{1}$
}

\begin{abstract}
ABSTRAK
Pengabdian yang bertujuan untuk meningkatkan pengetahuan dan keterampilan pembentuk peraturan desa di desa Pemogan . Mengingat pentingnya peraturan desa sebagai dasar pelaksanaan pengaturan di pemerintahan desa. Pengabdian telah dilaksanakan mulai bulan mei sampai bulan September 2018. Metode yang dilakukan adalah penyuluhan dan pelatihan tentang penyusunan peraturan desa.Pembentukan peraturan desa melalui tahap perencanaa, penyusunan, pembahasan, penetapan, pengundangan, penyebarluasan dan evaluasi.Perencanaan penyusunan rancangan Perdes ditetapkan oleh Kepala Desa dan BPD dalam rencana kerja Pemerintah Desa. Lembaga kemasyarakatan, lembaga adat dan lembaga desa lainnya di desa dapat memberikan masukan kepada Pemerintah Desa dan atau BPD untuk rencana penyusunan rancangan Perdes. Kerangka Struktur Peraturan Desa sebagai berikut : Penamaan/ Judul; Pembukaan; Batang Tubuh; Penutup; dan Lampiran (bila diperlukan).Hasil dari pengabdian adalah draft rancangan peraturan desa.
\end{abstract}

Kata kunci : Desa Pemogan dan Peraturan Desa

\begin{abstract}
Dedication that aims to improve the knowledge and skills of village regulations in the village of Pemogan Given the importance of village regulations as the basis for implementing arrangements in the village administration. Dedication has been carried out from May to September 2018. The method used is counseling and training on the preparation of village regulations. Formation of village regulations through planning, drafting, discussion, stipulation, enactment, dissemination and evaluation. Planning for drafting Perdes was determined by the Village Head and BPD in the Village Government work plan. Community institutions, customary institutions and other village institutions in the village can provide input to the Village Government and / or the BPD for planning plans for the Perdes. The Village Regulation Structure Framework is as follows: Naming / Title; Opening; Torso; Cover; and Attachments (if needed). Results of dedication are draft draft village regulations.
\end{abstract}

Keywords: Pemogan Village and Village Regulations

\footnotetext{
${ }^{1}$ Dosen Program Studi Ilmu Hukum Fakultas Hukum Universitas Udayana luh_astariyani@unud.ac.id
} 


\section{PENDAHULUAN}

Desa Pemogan terletak di Denpasar Selatan yang terdiri dari 17 ( tujuh bels) banjar yaitu Banjar Pemogan Kaja, Banjar Dalem, Banjar Panti, Banjar Islam, Banjar Jaba Jati, Banjar Jaba Tengah, Banjar Dukuh Tangkas, Banjar Sakah, Banjar Rangkan Sari, Banjar Glogor Carik, Banjar Gunug, Banjar Kajeng , Banjar Taruna Bhineka, Banjat Panti, Banjar Dalem, Banjar Asrama Praja Raksaka dan Banjar Mekar Jaya. Desa Pemogan secara geografis merupakan daerah dataran rendah. Di sebelah utara berbatasan dengan Kelurahan Pedungan di sebelah barat berbatasan dengan Desa Pemecutan Kelod, sebelah selatan dengan selat badung dan sebelah timur dengan Kelurahan Pedungan. Desa Pemogan memiliki luas sekitar 971.00 Ha dengan perincian sebagai berikut : tanah perorangan $608.877 \mathrm{Ha}$. tanah negara $282.256 \mathrm{Ha}$, tanah milik pura 2.050 Ha dan Tanah Hutan $77.817 \mathrm{Ha}$.

Perkembangan sistem pemerintahan desa sehingga terbentuknya Kota Administrasi Denpasar yang didalamnya termasuk pula Desa Pedungan diadakanlah pemekaran desa. Dengan demikian Desa Pedungan dimekarkan menjadi dua desa: desa induk Pedungan (selanjutnya kelurahan Pedungan) dan desa persiapan Pemogan. Secara definitif, desa persiapan Pemogan menjadi desa dalam wilayah kota administratif Denpasar, berdasarkan surat keputusan Gubernur Kepala Daerah Tingkat I Bali tertanggal 1 Juni 1982 Nomor: 57 Tahun 1982 tentang penetapan desa. Desa Pemogan didefinitifkan dengan nomor kode desa: 51.03.73.2008. Desa Pemogan merupakan salah satu desa dari sepuluh pemerintahan tingkat desa yang ada di wilayah Kecamatan Denpasar Selatan

Desa Pemogan adalah salah satu desa yang amat strategis bagi pusat kegiatan ekonomi Kota Denpasar hal ini dapat dibuktikan kendati pun berstatus sebagai desa bukan kelurahan, desa ini tidak pernah "tertidur" dari kegiatan ekonomi, baik mulai dari pasar rakyat, supermarket, gallerygallery, SPBU (depot bahan bakar minyak), dealer sepeda motor dan mobil, perumahanperumahan high class panggung barong dance, gelanggang olah raga demikian juga dari bidan desa sampai rumah Sakit International (BIMC Hospital dan SOS International Medical Clinic). Strategisnya desa ini juga dapat dilihat dari akses kota pemerintah dan pelayanan publik lainnnya. Jarak Desa Pemogan dengan Kecamatan Denpasar Selatan sekitar 3,00 Km, jarak dengan Kantor Walikota Denpasar, sekitar 5,00 Km. Jarak dengan pusat Pemerintah Provinsi Bali sekitar 6,5 Km. Jarak dengan Bandara Internasional Ngurah Rai sekitar 10,00 Km. Dan Jarak dengan Pelabuhan Benoa, Sanggaran Denpasar, sekitar 4,6 Km.

Tingginya intensitas kebutuhan akan tindakan pemerintahan, perkembangan ekonomi, hubungan antar masyarakat, hubungan administrasi pemerintah dan berbagai kepentingan dalam penyelenggaraan pemerintahan desa sangat memerlukan perangkat pengaturan terutama peraturan desa. Pentingnya perangkat hukum dalam bentuk peraturan desa sehingga perlu dilakukan pelatihan terkait dengan penyusunan peraturan desa yang baik. Penyusunan peraturan desa yang baik sebagaimana dimaksud dalam bagan di bawah ini : 


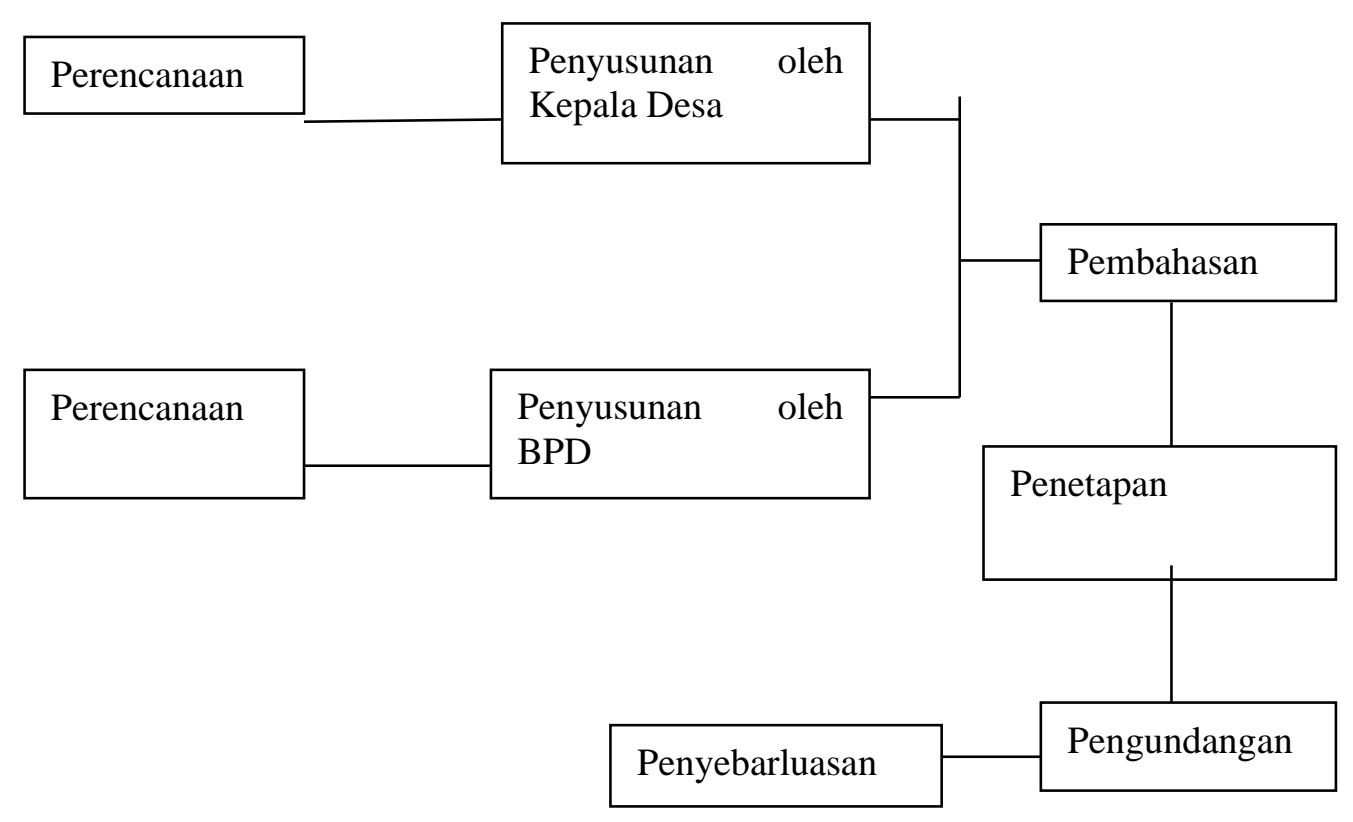

\section{METODE PELAKSANAAN}

Tingginya intensitas kebutuhan akan tindakan pemerintahan, perkembangan ekonomi, hubungan antar masyarakat, hubungan administrasi pemerintah dan berbagai kepentingan dalam penyelenggaraan pemerintahan desa sangat memerlukan perangkat pengaturan terutama peraturan desa. Menurut D.W.P Ruiter dalam kepustakaan di eropa kontinental yang dimaksud peraturan perundang-undangan mengandung 3 unsur : Norma hokum (rechtsnorm), berlaku ke luar (rechtnorm) dan bersifat umum dalam arti luas (algemeenheid in ruime zin).

Metode yang digunakan dalam kegiatan ini adalah metode ceramah dan tanya jawab dan para peserta juga diberikan contoh format dan perumusan norma hukum dalam peraturan desa. Metode pelaksanaan kegiatan pengabdian ini dilakukan dengan tahanapan sebagai berikut: Tahapan awal dilakukan dengan membentuk tim dan penyusunan TOR kegiatan dilanjutkan dengan pengurusan surat izin di Pemda Provinsi Bali dan Kota Denpasar. Tahapan kordinasi, dilakukan oleh tim pengabdi dengan aparat desa untuk menentukan waktu dan tempat pengabdian. Tahap pelaksanaan dilakukan mempergunakan metode bimbingan teknis kepada aparat desa berkaitan dengan teknik penyusunan peraturan desa.

\section{HASIL DAN PEMBAHASAN}

Hierarki adalah penjenjangan setiap jenis Peraturan Perundang-undangan yang didasarkan pada asas bahwa peraturan perundang-undangan yang lebih rendah tidak boleh bertentangan dengan peraturan perundang-undangan yang lebih tinggi. Berdasarkan Pasal 7 Undang-Undang Nomor 12 Tahun 2011 tentang Pembentukan Peraturan Perundang-Undangan, Jenis dan hierarki peraturan perundang-undangan yang berlaku di Negara Kesatuan Republik Indonesiaadalah sebagai berikut : 
a. Undang-Undang Dasar Negara Republik Indonesia Tahun 1945;

b. Ketetapan Majelis Permusyawaratan Rakyat;

c. Undang-Undang/Peraturan Pemerintah Pengganti Undang-Undang;

d. Peraturan Pemerintah;

e. Peraturan Presiden;

f. Peraturan Daerah Provinsi; dan

g. Peraturan Daerah Kabupaten/Kota.

Kekuatan hukum Peraturan Perundang-undangan sesuai dengan hierarkinya. Jenis Peraturan Perundang-undangan selain sebagaimana dimaksud di atas mencakup peraturan yang ditetapkan oleh Majelis Permusyawaratan Rakyat, Dewan Perwakilan Rakyat, Dewan Perwakilan Daerah, Mahkamah Agung, Mahkamah Konstitusi, Badan Pemeriksa Keuangan, Komisi Yudisial, Bank Indonesia, Menteri, badan, lembaga, atau komisi yang setingkat yang dibentuk dengan UndangUndang atau Pemerintah atas perintah Undang-Undang, Dewan Perwakilan Rakyat Daerah Provinsi, Gubernur, Dewan Perwakilan Rakyat Daerah Kabupaten/Kota, Bupati/Walikota, Kepala Desa atau yang setingkat.Peraturan Perundang-undangan sebagaimana dimaksud diakui keberadaannya dan mempunyai kekuatan hukum mengikat sepanjang diperintahkan oleh Peraturan Perundang-undangan yang lebih tinggi atau dibentuk berdasarkan kewenangan.

Peraturan Perundang-undangan pada tingkat Desa meliputi :

1. Peraturan Desa;

2. Peraturan Kepala Desa;

3. Keputusan Kepala Desa.

Materi muatan Peraturan Desa adalah seluruh materi muatan dalam rangka penyelenggaraan pemerintahan desa, pembangunan desa dan pemberdayaan masyarakat, serta penjabaran lebih lanjut dari ketentuan peraturan perundang-undangan yang lebih tinggi. Materi muatan Peraturan Kepala Desa adalah penjabaran pelaksanaan Peraturan Desa yang bersifat pengaturan. Materi muatan Keputusan Kepala Desa adalah penjabaran pelaksanaan Peraturan Desa dan Peraturan Kepala Desa yang bersifat penetapan.

Peraturan Desa dan Peraturan Kepala Desa diumumkan dalam Berita Daerah dilakukan oleh Sekretaris Desa.

Kerangka Struktur Peraturan Desa sebagai berikut :

1. Penamaan/Judul;

2. Pembukaan;

3. Batang Tubuh;

4. Penutup; dan

5. Lampiran (bila diperlukan).

\section{KESIMPULAN DAN SARAN}

Dari hasil pelatihan penyusunan peraturan desa yang dilakukan di desa Pemogan, dapat disimpulkan sebagai berikut: a) Peserta pelatihan yang dihadiri oleh Kepala Desa dan Perangkat Desa, Kepala Dusun dan Anggota Badan Perwakilan Desa memiliki keinginan yang tinggi untuk mnegikuti pelatihan. b) Di Desa Pemogan sudah memiliki beberapa peraturan desa baik Peraturan Desa tentang kewenangan berdasarkan hak asal usul dan kewenangan lokal berskala desa serta peraturan desa yang merupakan delegasi dari peraturan perundang-undangan yang lebih tinggi

Pelaksanaan kegiatan pengabdian ini dapat dilahat pada Gambar 

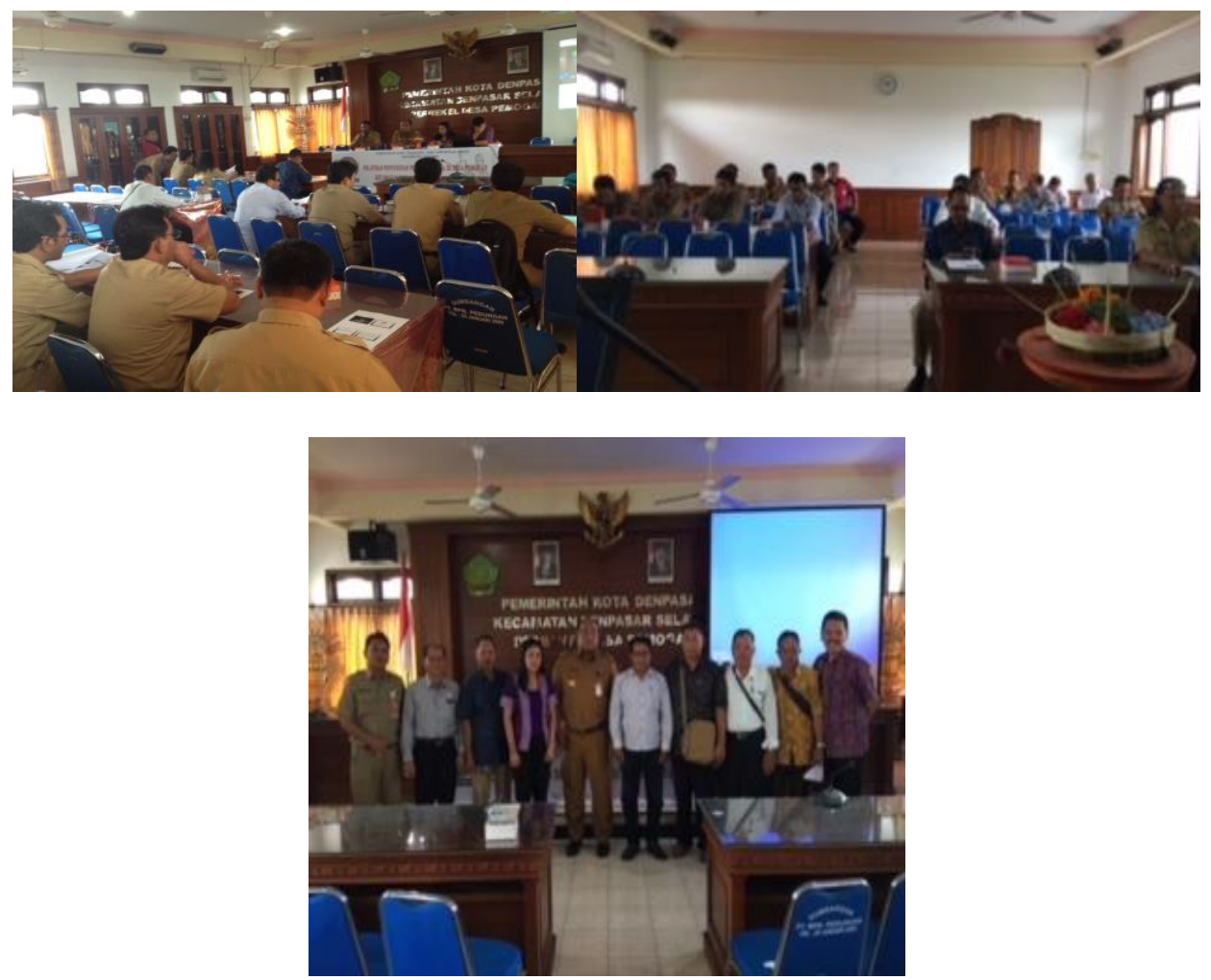

\section{UCAPAN TERIMA KASIH}

Penulis mengucapkan terima kasih kepada, Rektor Universitas Udayana, Ketua LPPM beserta staf terima kasih atas seleksi proposal dan atas dana yang diberikan lewat program pengabdian kepada masyarakat, kepada tenaga yang diberikan dalam pelaksanaan di lapangan, sehingga pengabdian kepada masyarakat terlaksana sesuai rencana.

\section{DAFTAR PUSTAKA}

A.H.S Attamimi , 1990, Peranan Keputusan Presiden Republik Indonesia Dalam Penyelenggaraan Pemerintahan Negara ( suatu studi analisis mengenai Keputusan Presiden yang berfungsi pengaturan dalam kurun waktu PELITA I- PELITA IV), Disertasi Doktor UI, Jakarta

Astariyani, Ni Luh Gede 2016, Penyusunan Materi Muatan Rancangan Peraturan Daerah Kabupaten Badung Tentang Pelayanan Publik, Laporan Penelitian HUPS FH Unud

Prayudha Wijaya, Adam Nugroho, Sugeng Rahardjo, (Eds), 2008, Panduan Membentuk Organisasi Pengelola Keuangan dan Aset Daerah (OPKAD), (Jakarta: LGSP/Local Governance Support Program) 